\title{
Álvares de Azevedo e a ambigüidade da orgia
}

\author{
Karin Volobuef
}

RESUMO: The tales of Noite na taverna ["Night in the Tavern"], by Álvares de Azevedo, are often described as "fantastic stories". As a matter of fact, instead of exploring the supernatural (as might be supposed) they are stories primary focused on human depravation, crimes and death. Although they are presented by the leading characters as reports of their past adventures, there are many indications that seem to go against their purported truthfulness: the tales have manifest marks of their fictional nature. As a result, the text can be seen as possessing an auto reflecting or meta-fictional meaning. What at first sight appears to be an orgy in a tavern is finally recognized as an orgy in poetry.

PALAVRAS-CHAVE: Álvares de Azevedo, Noite na taverna, Romantismo, noite, fantástico

Manuel Antônio Álvares de Azevedo (1931-1852) surgiu no céu da literatura brasileira como um cometa que anunciou brilhantes realizações mas cuja trajetória foi tolhida pela morte - que o arrebatou antes mesmo que completasse vinte e um anos. Além de criar uma produção lírica que marcou o seu nome como um dos grandes talentos de nosso ultra-romantismo, deixou ainda textos em prosa e de teatro. Exceto $A$ lira dos vinte anos, a maioria de suas obras (Noite na taverna, Macário, O livro de Fra. Gondicário, etc.) foi publicada postumamente.

Dentre a produção de Álvares de Azevedo, nossa atenção dirige-se aqui para Noite na taverna, que reúne contos usualmente rotulados como "fantásticos". O objetivo deste artigo é justamente discutir esse rótulo, propondo um exame do motivo da noite como instrumento essencial para se compreender o que Álvares de Azevedo entende por "fantástico”, termo que,

Karin Volobuef e docente do Departamento de Letras Modernas da FCL-UNESP/campus de Araraquara. 
aliás, ele próprio sugeriu pela boca de um de seus personagens:

- Agora ouvi-me, senhores! entre uma saude e uma baforada de fumaça, quando as cabeças queimam e os cotovelos se estendem na toalha molhada de vinho, como os braços do carniceiro no cepo gotejante, o que nos cabe é uma historia sanguinolenta, um daquelles contos phantasticos - como Hoffmann os delirava ao clarão doirado do Johannisberg! (AZEVEDO, 1942, v.2, p.92)

O conteúdo desses contos é sempre escabroso, consistindo o enredo em uma sucessão de crimes e atos ignominiosos que cada narrador apresenta como se fossem suas memórias, motivo pelo qual os contos são identificados pelo nome do personagem que o narra. Além do nome, nada ou quase nada se sabe desses personagens-narradores: nem de onde vêm, nem para onde vão, nem por que estão naquela taverna. As aventuras que eles narram tampouco esclarecem o mistério: longe de trazer uma elucidação, essas histórias são tão turbulentas e fantasiosas que o leitor não tem a impressão de ouvir confissões verídicas, mas sim de estar diante de fabulosas invenções, provavelmente engendradas pelas excessivas libações alcóolicas.

Álvares de Azevedo explora exclusivamente o lado sórdido do ser humano, sua face demoníaca. Os personagens puros e desprovidos de maldade vão, sob a influência dos maus, ou decair para o mundo dos vícios e crimes, ou resvalar para o abismo da morte. Em Noite na taverna não há finais felizes, casamentos ditosos, afetos baseados no respeito e honra; predominam apenas as perdas, mortes, separações, ultrajes, vinganças, desespero e loucura. É um mundo sem volta nem esperança.

Os protagonistas não são realmente agentes que decidem e realizam coisas, mas antes instrumentos conduzidos, de um lado pelo álcool, de outro, por seu fastio e cansaço ou ainda pela sensação de saciedade. São indivíduos sem passado e muito menos futuro - marionetes às quais apenas resta seguir seu destino perpassado de crimes e violências. E quem traça de antemão esse destino não é Deus e nem o diabo, mas a morte, o nada, o fim inescrutável.

\section{NOITE}

Noite na taverna é composta por dois planos narrativos: o da narrativamoldura, que trata dos personagens reunidos tarde da noite em uma taverna; e o das narrativas internas, que corresponde aos contos narrados por cinco dos rapazes ali presentes. O primeiro e o último capítulos ("Uma noite do 
século" e "Último beijo de amor") pertencem ao plano da narrativa-moldura, que retorna entre um conto e outro e assim funciona como aglutinador dos demais capítulos ou narrativas internas ("Solfieri", "Bertram" "Gennaro", "Claudius Hermann" e "Johann"). Esse plano interno em geral é contínuo, mas ocorrem às vezes interrupções em meio a um conto, retornando-se à taverna.

Solfieri é o primeiro a aceitar a incumbência de narrar um conto:

- Uma historia medonha, não, Archibald? falou um moço pallido que a esse reclamo erguêra a cabeça amarellenta. Pois bem, dirvos-ei uma historia. Mas quanto a essa, podeis tremer a gosto, podeis suar a frio da fronte grossas bagas de terror. (AZEVEDO, 1942, v.2, p.92-93)

A alusão ao "medonho" e ao "terror" suscitam no leitor a expectativa de eventos sobrenaturais e assustadores. A atmosfera sombria e enigmática da taverna, as fisionomias macilentas dos personagens, as inúmeras e variadas referências à morte formam uma constelação de temas e motivos que nos remete à literatura gótica, nascida em terras inglesas ainda no século XVIII sob a égide do pré-romantismo europeu.

O primeiro romance gótico foi $O$ castelo de Otranto (1764), de Horace Walpole, seguido de uma galeria de obras de autores como Clara Reeve, Sophia Lee, William Beckford, Charlotte Smith, Ann Ward Radcliffe, Matthew Lewis, Charles R. Maturin, para ficarmos apenas com os mais conhecidos. O romance gótico, ou gothic novel, move-se em princípio no elemento fantasmagórico, criando o efeito de terror pela ambientação em lugares lúgubres e solitários, como castelos sombrios, cemitérios abandonados, passagens secretas e masmorras. Seus recursos técnicos são o mistério e o suspense, e seu enredo está centrado na oposição entre inocência e perversidade, na luta entre o Bem e o Mal.

Para uma análise de Noite na taverna, merecem atenção romances como Vathek (1781), de William Beckford, e O monge (1796), de Matthew Lewis, cujas páginas aliam o sobrenatural ao erótico, explorando temas ligados ao exotismo e sensualidade, vícios e crimes. Esse também é o estofo de Noite na taverna, cuja filiação ao gótico deve ter sido intermediada por Byron e E. T. A. Hoffmann. Enquanto Hoffmann mostrou sua afinidade com Matthew Lewis n' Os elixires do diabo (ver NEHRING, 1992/1993), Byron foi buscar sua marca de decadência e melancolia, erotismo e depravação, rebeldia e morbidez na literatura gótica (ALLEN, 1958, p.99). Vale ainda notar que Doge und Dogaresse (1819), de Hoffmann, e Marino Faliero (1821), de Byron, tratam de um mesmo episódio histórico envolvendo um doge de 
Veneza - e a leitura desses textos deixou seus vestígios em "Bertram".

Admirador de Byron e Hoffmann, Álvares de Azevedo retoma do gótico os temas escabrosos (assassinatos, incesto, necrofilia, etc.) e o ritmo acelerado que marca a sucessão de aventuras. Retoma também a atmosfera insólita, como se vê em "Solfieri":

Eu me encostei á aresta de um palacio. A visão desappareceu no escuro da janella e daí um canto se derramava. Não era só uma voz melodiosa: havia naquelle cantar um como chôro de phrenesi, um como gemer de insania: aquella voz era sombria como a do vento á noite nos cemiterios cantando a nenia das flôres murchas da morte. $[\ldots]$ A noite ia cada vez mais alta: a lua sumira-se no céu [...]. Aqui, ali, além eram cruzes que se erguiam de entre o ervaçal. Ella ajoelhou-se. Parecia soluçar: em torno della passavam as aves da noite. (AZEVEDO, 1942, v.2, p.95)

Mas - é importante notar - não retoma o sobrenatural. Embora os críticos costumem referir-se a estes contos como "fantásticos" e Eugênio Gomes (1953, p.13) fale de "histórias de terror e perversões" que exerceram "poderosa influência sôbre alguns espíritos inclinados à sedução do horror" - nada há neles que exceda o natural. Não nos deparamos com fantasmas nem assombrações, mas com aventuras no estilo dos romances de capa e espada, em que donzelas são raptadas enquanto dormem, outras são vendidas a piratas, jovens mancebos duelam à luz da lua e vultos atravessam sorrateiros as sombras noturnas. Nas palavras de Décio de Almeida Prado (1996, p.141), "As aventuras pessoais narradas permanecem na categoria do estranho ou do insólito [...], tendo este caráter menos pelos incidentes tomados um a um do que por seu acúmulo na vida de uma mesma pessoa".

Mas, se buscarmos as teorias sobre o fantástico, vemos que tanto para Todorov (1975, p.30-31) como para outros estudiosos, o gênero nasce da hesitação ou de algum tipo de tensão entre um elemento racionalmente explicável e outro de natureza sobrenatural. Diante disso, torna-se questionável a caracterização de Noite na taverna como texto "fantástico". Não podemos, porém, deixar de notar que a designação "narrativas fantásticas" também é empregada por críticos que se referem não à dimensão sobrenatural, mas ao caráter frenético, extravagante, hiperbólico:

conúbios sexuais forçados ou resultantes da traição, do ludíbrio, do engano, chegando mesmo ao incesto (cap. VI, Johann) e à antropofagia (cap. III, Bertram); em suma, o fantástico, que deixa transparecer, para além de Byron, o influxo de Hoffmann e seus contos de horror. (MOISÉS, 1984, p.150) 
Tendo em vista esse impasse e a variedade de sentidos cobertos pelo termo "fantástico" quando aplicado ao texto de Azevedo, preferimos basear nossa análise no motivo da noite. Hannes Leopoldseder (1973, p.77-93; ver também VOLOBUEF, 1999, p.66-70) identificou duas formas pelas quais o Romantismo tende a empregar a noite. Em primeiro lugar, há o emprego literal de "noite" enquanto período cronológico, ou seja, as horas em que o sol não é visível e o mundo está escuro. Em segundo lugar, "noite" tem um sentido figurado, referindo-se a um conjunto de temas e imagens ligados à face obscura (inconsciente) do ser humano: loucura, alucinação, estado hipnótico, impulsos destrutivos, distúrbios de toda sorte, etc. No primeiro caso, trata-se das sombras encobrindo uma parte da Terra; no segundo caso, temos as penumbras da alma humana.

Para a análise do motivo da noite no texto de Álvares de Azevedo, devemos considerar os dois níveis narrativos - o da narrativa-moldura e o das narrativas internas (WIESE, 1963, p.36s) - que se distinguem no que se refere à ligação com a realidade e no que diz respeito à noite.

A narrativa-moldura, na qual se enxertam os vários contos, caracteriza-se pelo predomínio do diálogo sobre a descrição, o que aproxima o texto do teatro, onde o expectador recebe as informações diretamente dos personagens e não de um narrador. Em Álvares de Azevedo, isso cria um "efeito de realidade", uma vez que o leitor tem a impressão de observar algo em primeira mão, sem a intermediação de um terceiro.

Tudo o que ocorre na narrativa-moldura - todas as falas e gestos dos rapazes na taverna -, passa-se ao longo de uma noite. A noite tem o papel de "arcabouço espaço-temporal" (LEOPOLDSEDER, 1973, p.77), ou seja, um fundo sobre o qual se dispõe todo o texto. Esta ambientação noturna é responsável pela atmosfera tétrica e pesada que perpassa a narrativa como um todo. Como a noite é o fim do dia, tudo se nos apresenta como extinto, acabado: Noite na taverna principia com a fala de Johann pedindo que os outros parem de cantar; tem-se, a impressão de que o local já foi abandonado pelos demais fregueses, permanecendo ali apenas os narradores das histórias e as mulheres já ébrias e adormecidas pelo chão. Em vários momentos, à vezes em meio à narrativa de um conto, alguém reclama por mais garrafas de vinho. Por fim, todos se calam, vencidos pela fadiga e excesso de álcool.

No nível das narrativas internas, a noite - embora seja fator de extrema relevância - não se apresenta como período cronológico único: muitos episódios passam-se à noite, mas outros tantos transcorrem à luz do dia. Mais do que isso, percebe-se nesse nível interno que a noite reveste-se de novo significado, formando um conjunto de motivos e temas lúgubres. $\mathrm{O}$ fenômeno natural (paisagem noturna) cede lugar a fenômenos mirabo- 
lantes, como a loucura, o sonambulismo e, principalmente, a disposição para o crime. Assim, desejos diabólicos, vinganças, traições e todo tipo de perversidade impelem a ação, que sempre resulta no ultraje da inocência, hospitalidade e confiança. A "noite" torna-se o espaço da transgressão social, da marginalidade, da violência.

Se o dia é o período da claridade, em que tudo se revela, a noite esconde com suas sombras o lado negativo do ser humano e da sociedade. A noite abre as portas para os instintos e desejos animalescos, para o obsceno e proibido, para os vícios e crimes. A noite, enfim, é o momento em que se libera no seio da sociedade aquilo que fermenta dentro do ser humano, mas sempre se procura encobrir: sua propensão à transgressão e ao desregramento.

Em Álvares de Azevedo (à semelhança do que se vê em Byron e Hoffmann), a recuperação de elementos góticos está ligada à revolta contra a moral burguesa e a rigidez de costumes, que, em última análise, se revela hipócrita, já que procura encobrir o que de sórdido e bárbaro pulula sob a superfície austera:

Estamos sem dúvida ante um produto do romance negro, mais particularmente da modalidade que os franceses chamam de 'frenético'. Narrativa frenética é de fato esta que Satan desvenda a Macário como uma espécie de experiência-limite, marcada pelo incesto, a necrofilia, o fratricídio, o canibalismo, a traição, o assassínio - cuja função para os românticos era mostrar os abismos virtuais e as desarmonias da nossa natureza, assim como a fragilidade das convenções. Associados a isto a modo de correlativo, a noite, a tempestade, o raio, o naufrágio, o tufão -, constituindo o arsenal daquele 'belo sublime' que podia costear o 'horrível', como indicam algumas páginas críticas de Álvares de Azevedo. (CANDIDO, 1987, p.17)

\section{RADIOGRAFIA POÉTICA}

As últimas linhas de Macário mostram o protagonista e Satã acercando-se de uma janela através da qual se pode vislumbrar um grupo de bebedores em uma orgia:

M.: Onde me levas?

S.: A uma orgia. Vais ler uma pagina da vida; cheia de sangue e de vinho - que importa?

$[\ldots]$ 
M.: Eu vejo-os. É uma sala fumarenta. Á roda da mesa estão sentados cinco homens ebrios. Os mais revolvem-se no chão. Dormem ali mulheres desgrenhadas, uma lividas, outras vermelhas... Que noite!

S.: Que vida! não é assim? Pois bem! escuta, Macario. Ha homens para quem essa vida é mais suave que a outra. $\mathrm{O}$ vinho é como o opio, é o Lethes do esquecimento... A embriaguez é como a morte...

M.: Cala-te. Ouçamos. (AZEVEDO, 1942, v.2, p.84)

Antonio Candido (1987, p.14-15) entende esse final da peça como uma "ponte" para Noite na taverna, que seria, nessa interpretação, a continuação de Macário. Temos de início a coincidência de local e situação (nos dois casos temos cinco homens embriagados numa taverna, rodeados de mulheres já adormecidas), além disso, a expectativa contida na última fala remeteria justamente às conversas e contos de Noite na taverna.

A descoberta de Candido, que Prado (1996, p.141) considerou "um desses achados interpretativos que, uma vez feitos, parecem óbvios", levanos a deduzir que a taverna não está localizada em algum rincão da Europa - como fazem supor as afirmações dos narradores, que dizem ter vivido suas aventuras na Itália, França, Espanha. Ao contrário disso, a taverna está firmemente plantada na capital paulista, cenário de Macário. Isso inclusive parece confirma-se no primeiro capítulo, quando um dos rapazes exclama: "E pois ergamo-nos, nós que amarellecemos nas noites desbotadas de estudo insano" (AZEVEDO, 1942, v.2, p.92). Percebemos que os extravagantes aventureiros não passam de simulacro, e que estamos diante de estudantes da Faculdade de Direito em São Paulo.

Aliás, a prática de adotar nomes estrangeiros - pseudônimos inspirados em personagens de Byron - era usual entre os membros da Sociedade Epicuréia em São Paulo (Almeida, 1962, p. 202). Além disso, Aurélio Buarque de Hollanda (apud ROCHA, 1991, p.13) identificou os nomes dos protagonistas de Noite na taverna como extraídos da obra de Byron, exceto Gennaro que é proveniente de Victor Hugo. À primeira vista parece haver diversas nações implicadas nos nomes dos personagens da narrativa-moldura: Solfieri, Gennaro, Maffio, Giorgia são de origem italiana; Bertram, Artur e Archibald indicam procedência inglesa; Arnold, Hermann e Johann vêm da Alemanha. A despeito disso, Serroni (1991, p.46) já comentou que essa diferença de nacionalidade é superficial, pois nenhum desses personagens carrega qualquer traço nacional específico, não havendo nada no texto que remeta a costumes, linguagem ou outra peculiaridade própria desses países.

Tudo parece indicar, portanto, que os personagens de Noite na taverna são estudantes brasileiros em São Paulo que, em suas reuniões noturnas, 
adotam nomes literários ou romanceados. Como resultado, suas memórias envolvendo viagens e extravagâncias (contos) perdem a verossimilhança e se revelam fictícias, inventadas, pois a credibilidade das narrativas internas depende da credibilidade da narrativa-moldura. Em outras palavras, tratase de um texto que carrega em si as pistas de sua própria ficcionalidade um texto que, em última análise, não pretende contar uma história e entreter o leitor, mas revelar seu estatuto ficcional. É o poético falando de si mesmo - não pela voz de personagens (que, afinal, não têm vida nem identidade, já que tudo é simulação), mas pela própria voz de Álvares de Azevedo, que se dirige ao leitor disfarçado de Bertram, Johann, etc.

Desde o início os contos trazem a marca do relato, não da vivência do momento. O leitor não presencia tanto o gesto, mas a palavra narrada. $\mathrm{Na}$ narrativa-moldura, os próprios rapazes reunidos na taverna encarregam-se de sugerir a natureza fictícia de suas pretensas aventuras (narrativas internas), como exemplifica a reação dos demais, quando Solfieri se dispõe a contar algo de sua vida: "- Solfieri! Solfieri! aí vens com teus sonhos!" (AZEVEDO, 1942, v.2, p.92-93). O mesmo pode ser flagrado nas palavras de Claudius Hermann: "- Pois bem! quereis uma historia? Eu pudéra contal-as, como vós, loucuras de noites de orgia - mas para que?” (AZEVEDO, 1942, v.2, p.130). E também o narrador impessoal sugere tratar-se de invenções em lugar de lembranças: "O velho esvaziou o copo, embuçou-se e saiu. Bertram continuou a sua história" (AZEVEDO, 1942, v.2, p.115 - grifo nosso).

O caráter de ficcionalidade do texto também é reforçado pelas palavras finais: "A lampada apagou-se." (AZEVEDO, 1942, v.2, p.164) - conclusão que sugere o encerramento de uma peça no palco, corroborando ainda mais a análise de Antonio Candido sobre a simbiose com Macário. A extinção da luz funciona também como dupla metáfora da morte, tema que, ao lado da noite, permeia toda a obra. De um lado, a metáfora remete à morte enquanto o nada absoluto, trevas permanentes que o cético prevê em seu futuro; de outro, remete à cena de assassinato e suicídio no capítulo final, em que perecem vários personagens: Johann, Giorgia e Artur, que participaram tanto do plano da narrativa-moldura como do das narrativas internas. Neste último caso, a extinção da chama vital dos três personagens confunde-se com a oclusão do próprio ato de narrar: Johann, o contador do último conto, adormeceu e foi morto sem passar a palavra adiante. Uma vez silenciada a palavra, acaba-se a vida, acaba-se a luz. É o que teria sucedido a Sherazade, se tivesse interrompido sua longa seqüência de contos.

E, como demonstra o exemplo de Johann, sono e morte são apenas dois estágios diferentes do avanço da escuridão, do império da noite. $\mathrm{O}$ sono ainda não é o nada absoluto, mas já comporta profundezas obscuras e insondáveis, e representa um mergulho no lado noturno do ser humano. 
Dando plena vazão a essa forma de "noite", o texto de Álvares de Azevedo contém inúmeras referências ao sonho e à loucura, o que gera uma atmosfera de incerteza, fazendo as peripécias narradas soarem como ilusões e devaneios. A ambientação na taverna, carregada de imagens da embriaguez, torna os relatos dos rapazes ainda mais duvidosos: como eles certamente se excederam na bebida, é inevitável presumir que também se excedem na narração, tendendo a exagerar, adulterar e inventar parcial ou totalmente os eventos. Assim, as narrativas tingem-se irremediavelmente da cor do fictício e imaginário. Por fim, os contos vão acumulando barbaridades tão atrozes, e numa sucessão tão alucinante, que acabam produzindo um efeito curioso: a atrocidade torna-se inverossímil, quase hilariante.

Mas o texto só parecerá inverossímil para quem procurar nele a representação do mundo real. E esse de forma alguma é o objetivo de Noite na taverna, obra que transborda subjetivismo romântico. Como sintoma desse subjetivismo exacerbado, tudo no texto gira em torno do indivíduo, não havendo de fato uma relação entre personagens, apenas a manifestação do individual. Isso fica ainda mais evidente quando observamos como os personagens se encontram e convivem. Em cada uma das narrativas internas, o respectivo narrador, que é também o protagonista, é o centro em torno do qual orbitam os outros personagens. A despeito de reconhecermos que o tipo de foco narrativo favorece a perspectiva individual, o que se passa nos contos vai muito além dessa medida: quaisquer que sejam as situações, os lugares ou as eventuais ligações afetivas, o protagonista-narrador concentra-se exclusivamente nos seus próprios sentimentos e sensações. Não estamos diante de um narrador que não pode conhecer o que se passa no íntimo dos demais personagens (por ser ele próprio também um personagem), mas um narrador que não quer conhecer isso, pois pouco se importa com quem o cerca. Os personagens com quem contracena nada mais são para ele do que meios para atingir seus fins egoístas. Com isso, os personagens secundários sequer têm espaço para sua própria ação: eles dificilmente agem, restando-lhes apenas servir de objeto para a ação do personagemnarrador do conto.

Quanto aos cinco protagonistas, todos compartilham das mesmas motivações, desejos, modos de agir e pensar. Em suma, todos agem segundo um mesmo padrão de comportamento lascivo e inconseqüente, característico de quem não reconhece o outro, apenas a si próprio. Suas personalidades são idênticas, como se os cinco fossem apenas um. Ao invés do múltiplo (variação), encontramos a manifestação do único (repetição) - a exclusiva existência daquele que está fechado em si mesmo.

Concomitantemente, o espaço é construído segundo essa tendência que sempre privilegia o "eu" em detrimento do "tu": quase toda a ação desenro- 
la-se em ambientes fechados (delimitados), não a céu aberto (sem limites). Nas poucas cenas em que os personagens se encontram ao ar livre, a vista em nenhum momento se expande até o horizonte, o que impede o leitor de ganhar uma sensação de amplitude ou liberdade. $\mathrm{O}$ ambiente, assim, não abrange o múltiplo, mas restringe-se ao unitário e enclausurado. Em vista dessa limitação, o espaço torna-se opressivo, sufocante, desalentador.

Dois aspectos mostram-se, assim, decisivos na construção do texto: a perspectiva limitada ao indivíduo e a atmosfera de opressão. Em todos os contos vemos um indivíduo, o sujeito-narrador, em choque com aqueles que encontra, acabando por levá-los à ruína e destruição. Tudo o que acontece (da mentira ao assassinato, do incesto à necrofilia) são atos socialmente condenáveis, perpetrados às escondidas e em meio às trevas. Com isso, $\mathrm{O}$ texto de Azevedo constitui-se em uma negação da sociedade: a ação do livro, formada por uma sucessão de crimes, revela a dimensão anti-social de Noite na taverna. Aqui não há coletividade - uma vez que não imperam leis nem são respeitadas normas de conduta moral -, apenas a subjetividade reina absoluta. E, na medida em que o sujeito não se dobra a qualquer código moral ou ético (instância supra-individual), ele se deixa levar por seus caprichos e instintos desenfreados. Azevedo concentra-se, dessa forma, na face oculta do homem, nas entranhas mais sórdidas e usualmente reprimidas pela sociedade. Na narrativa-moldura, ambientada na taverna, é o álcool que dá sinal verde para que essas entranhas aflorem; nas narrativas internas, é basicamente a paixão carnal que leva ao crime.

Para Arlenice Almeida (1991, p. 58-63 em especial), Noite na taverna reflete o desencanto dos jovens estudantes de Direito perante à realidade brasileira, que reúne, de um lado, um povo imerso na pobreza e ignorância; de outro, um Estado repressivo que, desde a Inconfidência, sempre sufocou os anseios populares. Reina o atraso econômico, cultural e político, percebido com angústia por esses estudantes que formam a futura nata da burocracia estatal da época. Segundo a estudiosa, Álvares de Azevedo dá vazão às desilusões de toda uma geração que, embora destinada a galgar o poder, não vê no futuro qualquer possibilidade concreta de realização das inovações que crê serem necessárias.

Tal falta de perspectivas reflete-se em Noite na taverna, que se recusa a fornecer uma representação mimética, um retrato fiel e objetivo do real: Álvares de Azevedo não está tentando convencer-nos de que o mundo é assim como vemos nas páginas do texto. Mas, a despeito dessa ausência da realidade, o mundo não deixa de se fazer sentir, estando presente sob forma de um pólo contrastante que, mesmo oculto, está em permanente oposição ao fantasioso e desmedido. Mais do que isso: percebe-se que as extravagâncias e exacerbações são relatadas apenas para contrariar e afrontar os 
valores vigentes. Em outras palavras: o propósito é chocar, é deixar à mostra o desdém e a descrença na sociedade e no homem. A título de ilustração, veja-se o início da narrativa de Solfieri:

Sabei-lo. Roma é a cidade do fanatismo e da perdição: na alcova do sacerdote dorme a gosto a amasia, no leito da vendida se pendura o Crucifixo livido. É um requintar de gozo blasphemo que mescla o sacrilegio á convulsão do amor, o beijo lascivo á embriaguez da crença! (AZEVEDO, 1942, v.2, p.94)

Não teríamos aqui um retrato do que acontece no Brasi? Não seria esta passagem a expressão de revolta do rapaz que vê na sociedade de seu tempo "dois pesos e duas medidas" - ou seja, de um lado, uma rígida moral baseada nos ensinamentos cristãos e, de outro, a desobediência a esses preceitos morais por parte daqueles que deveriam justamente fazê-los prevalecer? Nesse sentido, não é demais lembrar que também em Macário há diversas passagens que denunciam a luxúria e o desregramento moral. Diante deste quadro, Azevedo opõe-se à hipocrisia e assume uma atitude francamente impiedosa, sarcástica, insolente e sacrílega, como analisa Candido:

Pessimismo e sadismo condicionam a manifestação mais espetacular e original do espírito romântico - o satanismo, a negação e a revolta contra os valores sociais, quer pela ironia e o sarcasmo, quer pelo ataque desabrido. Aquelas gerações assistiram a uma tal liquidação de valores éticos, políticos e estéticos, que não poderiam deixar de exprimir dúvida ante os valores, em geral, e curiosidade por tudo quanto fosse exceção ou contradição das normas. $\mathrm{O}$ crime, o vício, os desvios sexuais e morais, que a literatura do século XVIII começara a tratar com cinismo ou impudor, entram de repente em rajada para o romance e a poesia, tratados dramaticamente como expressões próprias do homem, tanto quanto a virtude, a temperança, a normalidade. (CANDIDO, 1981, p.33)

Expressão dessa afronta à realidade é a quantidade de atos e sentimentos que a sociedade condena: luxúria, covardia, traição, ingratidão, desrespeito pelo próximo pululam nas páginas da Noite na taverna. Não há sentimento de justiça, probidade, remorso ou compaixão. Os rapazes na taverna, que contam suas pretensas aventuras, são como anjos da morte e da destruição, semeando a total ruína por onde passam. Percebe-se claramente que o texto não pretende provocar susto ou medo no leitor (como seria o caso no romance gótico tradicional), e sim produzir o estranhamento e a repulsa. E, como era de se esperar, as "noites" de vícios e devassidão 
narradas por Álvares de Azevedo chocaram o público leitor da década de 1850 (AMARAL, 1931, p. 347). Podemos, nesse sentido, interpretar o texto como um grito de liberdade, uma explícita rejeição das virtudes defendidas pela sociedade burguesa - aspecto, aliás, já presente em Byron:

Á maneira do bardo magnifico que foi um enscenador de temporaes, naufragios e avalanches, Alvares de Azevedo bem que desejaria dramatizar a sua propria vida. [...] Mais facil era ser bohemio, irregular, anti-burguez, traspassando ao negociante ou ao lente da Paulicéa o desdem satirico com que Byron fulminara os banqueiros e os professores britannicos nas estrophes do "Childe Harold” ou do "Don Juan". (GRIECO, 1932, p.35)

Contrariar as expectativas de seu público, confrontando-as com um mundo de vícios e ambições carnais desenfreadas, foi a maneira encontrada por Álvares de Azevedo para nadar contra a maré do status quo e expressar sua rebeldia:

À boêmia espiritual respondem certas fumaças liberais e anarcóides, provàvelmente de fundo maçon, de um maçon romantizado, que é a côr política de Álvares e dos meios acadêmicos que praticava.

Confrontadas, porém, com a ideologia bolorenta do grupo de Magalhães, essas veleidades de radicalismo do jovem Manuel Antônio significam um passo avante na formação de uma corrente democrática que, no âmbito das Academias de Direito e das sociedades secretas, fazia oposição (ainda que só retórica) ao imobilismo monárquico e aos abusos do clero. Testemunho de revolta juvenil é o poemeto heróico dedicado a Pedro Ivo, rebelde praieiro [...]. (BOSI, s.d., p.123)

Em relação a esse aspecto, Haddad já chamou a atenção para o fato de que

Não tem sido devidamente estudado o pensamento político de Álvares de Azevedo que alguns, mais levianamente, supõem inexistente. [...] A Revolução Francesa estremece no pensamento político de Álvares. O seu sonho liberal-democrático pode ser documentado sem maiores dificuldades. Não é difícil ir respingando citações. Ao poeta da "Lira dos Vinte Anos", Byron sugere o drama da Revolução Francesa [...]. (HADDAD, 1960, p.74)

${ }^{1}$ Também Brito Broca (1979, p.234) refere-se ao byronismo como sendo "não-conformista e anti-social". 
Assim, embora a realidade concreta não seja retratada e descrita (tal como um José de Alencar ou um Visconde de Taunay fariam), ela é o verdadeiro impulsionador de Noite na taverna, que contém em seu âmago a revolta contra essa realidade. Em suma, o texto de Álvares de Azevedo não é acerca do mundo real mas contra ele, tal como está constituído e é experimentado pelo poeta no seu dia-a-dia.

E a arma empunhada contra o mundo é a poesia. Noite na taverna é uma alternativa a esse universo real em que o poeta não tem como realizar suas fantasias e anseios, cuja concretização apenas é possível no espaço literário. Isso se evidencia na maneira como os poetas e a poesia são representados no texto. Como exemplo, vejamos o trecho em que um desconhecido entra na taverna trazendo uma caveira, ao que os moços perguntam pela identidade do morto e alguém opina:

- Talvez um poeta - talvez um louco.

- Muito bem! adivinhaste. Só erraste não dizendo que talvez ambas as coisas a um tempo. Seneca o disse - a poesia é a insania. Talvez o genio seja uma alucinação, e o enthusiasmo precise da embriaguez para escrever o hymno sanguinario e fervoroso de Rouget de l'Isle, ou para, na criação do painel medonho do Christo morto de Holbein, estudar a corrupção no cadaver. Na vida mysteriosa de Dante, nas orgias de Marlowe, no peregrinar, de Byron havia uma sombra da doença de Hamleto: quem sabe? (AZEVEDO, 1942, v.2, p.114)

Aqui, como em outras passagens, sobressai uma concepção de poesia em que o veio poético brota da loucura e do desvario, de noites de insônia, da entrega à bebida, dos excessos de toda sorte ${ }^{2}$. Também podemos dizer: para Álvares de Azevedo, poesia é sinônimo de delírio, de contestação, de liberação total dos impulsos. E, considerando que a espinha dorsal de Noite na taverna são as loucuras e aberrações, que formam a essência da poesia,

\footnotetext{
${ }^{2}$ Aliás, no entender de Brito Broca (1979, p.151), era muito disseminada durante o Romantismo a concepção de que o álcool propicia a inspiração. Segundo Eugênio Gomes (1958, p.6263), o estado de exaltação não precisa necessariamente ser originado por bebida forte; a própria literatura pode levar o poeta ao delírio febril: "Apesar de haver celebrado as excelências do cognac e não obstante o ardor com que descreveu algumas cenas de esbórnias, em prosa e verso, o artista da 'Noite na Taverna' embriagou-se principalmente de leituras. E, por êsse meio, atingiu aquêle peculiar misticismo em que o precedeu Gérard de Nerval, caracterizado precisamente pelo état de lecteur. Nesse estado, de Goethe a Shelley ou Alfred de Musset, produziram os românticos as suas principais obras, cuja trama de alusões obriga a um trabalho penoso quando se quer captar o jôgo de seus contactos com as idéias do tempo ou do passado."
} 
pode-se concluir que o que esse texto faz é realizar uma verdadeira radiografia da poesia, segundo a concepção estética de Álvares de Azevedo. Ao recorrer a esta gama de motivos e, o que é mais significativo, ao concentrar-se unicamente neles (não desenvolvendo mais nenhuma outra problemática no texto), nosso autor faz um livro que é o completo retrato daquilo que, para ele, sintetiza a arte e a poesia. Noite na taverna não narra histórias, mas narra a própria arte narrativa.

E, uma vez que a poesia se encontra em simbiose com os estados "exaltados", dissociando-se da reflexão sóbria e comedida, a escritura de Noite na taverna traz a marca dessa exaltação dionisíaca: ela cria um redemoinho em que determinadas imagens, evocações literárias, motivos e temas sempre retornam, formando um turbilhão que gira sobre si mesmo. Cada um de seus contos representa, assim, uma reencenação dos mesmos elementos. O começo é, ao mesmo tempo, o seu fim. Não é de se espantar que Décio de Almeida Prado (1996, p.142) tenha se referido à Noite na taverna como uma "orgia verbal".

Soterrada nesse colossal esteticismo, Noite na taverna não se debruça sobre o "homem comum", ou seja, aquele que está imerso no desempenho rotineiro de uma profissão e que vive no seio da família sem quaisquer ambições amorosas extravagantes ou aventureiras. Toda a vida cotidiana está banida desta obra de Azevedo. Os personagens encontram-se permanentemente às voltas com duelos, viagens, tempestades, e, a cada passo, sucedem-se as paixões avassaladoras. Fora desses envolvimentos eróticos, os personagens não têm passado nem futuro, pois é aí que está todo o seu viver. Ao expirar o fogo da paixão, só há duas alternativas: ou alguém morre ou o conto termina.

Aqui, como em outras obras de Álvares de Azevedo, o amor forma o eixo central. Contudo, o viés pelo qual ele é tratado sofre variações, percebendo-se uma contundente dualidade: ora o amor é abordado numa perspectiva idealizante, lírica e emotiva, ora sob um prisma de cinismo, descrença, deboche e licenciosidade. $\mathrm{O}$ amor em Álvares de Azevedo tem um lado "saturnal" e um lado de "candura", conforme expressou Eugênio Gomes (1953, p.13).

Em Noite na taverna, cada um desses dois pólos encontra seu correlato numa figura feminina: de um lado, a virgem imaculada e pura; de outro, a mulher prostituída. A virgem é inevitavelmente linda e perfeita; a prostituída é feia e costuma ser descrita com pele macilenta, olheiras, corpo e rosto desfigurados pela velhice ou pelos vícios. Cada uma delas estimula uma reação masculina diferente: a mulher-anjo, idolatria; a mulher-pervertida, vilipêndio. Em conseqüência, diante da mulher pura e intocável, temos o homem terno e amoroso, que ama à distância ou, mais precisamente, ve- 
nera seu ídolo inalcançável. Já em vista da mulher que se entrega, surge o homem ignóbil e depravado, muitas vezes criminoso e que se rendeu aos excessos e vícios. Como exemplo de adoração, vejamos um trecho da história de Gennaro:

Uma noite eu disse a Nauza que a amava: ajoelhei-me junto della, beijei-lhe as mãos, reguei seu collo de lagrimas. Ella voltou a face: eu crí que era desdêm, ergui-me. [...]

- Adeus pois: perdoai-me se vos offendi: meu amor é uma loucura, minha vida é uma desesperança - o que me resta? Adeus, irei longe - longe daqui... talvez então eu possa chorar sem remorso...

Tomei-lhe a mão e beijei-a.

Ella deixou sua mão nos meus labios. [...]

Tudo o mais foi um sonho: a lua passava entre os vidros da janella aberta, e batia nella: nunca eu a vira tão pura e divina! (AZEVEDO, 1942, v.2, p.124)

Assim é o Gennaro que se deslumbrou pela pureza de Nauza, bem outro é o Gennaro que engravidou Laura. Indiferente à angústia da moça, ele friamente a abandona. Se a virgindade enobrece e santifica, a sexualidade degenera e rebaixa. Dessa forma, o homem é o fator de transformação da mulher: ao macular o que antes era puro, ao perverter o que era inocente, ele leva a mulher a cair de posição, fazendo-a passar de anjo para "perdida”. Depois da desgraça, a mulher já não mais é merecedora de amor ou compaixão; seu único destino é a rua ou a morte. Longe de ser santificado, o amor na taverna é como uma chaga que corrompe o homem e lhe rouba o que quer que tenha de nobre ou sublime. Como disse Jordão (1955, p.21), "Em todos os contos da 'Noite na Taverna' o amor é fôrça maléfica, destruindo no homem todo sentido de grandeza, reduzindo-o à mais abjeta condição."

As relações sexuais que se sucedem ao longo do texto quase sempre são atos ilícitos e criminosos (estupro): ora o homem rapta o corpo de uma moça tida como morta, ora consegue acesso ao quarto de alguém que dorme ou está entorpecida. Outras vezes, ela está consciente, mas desconhece a verdadeira identidade de seu amante. Há casos em que a relação carnal é consentida, mas aí o episódio costuma vir acompanhado de circunstâncias conturbadas, como ocorre com a mulher do comandante ("Bertram"), que é possuída em meio a uma batalha contra os piratas; ou com Nauza, que cede a Gennaro enquanto seu marido se encontra em outro quarto junto ao cadáver da filha.

A única mulher que não sucumbe é Ângela, a espanhola que acompanhou Bertram vestida de homem e que "Bebia já como uma Inglesa, fumava como uma Sultana, montava a cavallo como um Arabe, e atirava as ar- 
mas como um Espanhol" (AZEVEDO, 1942, v.2, p.105). Ou seja, a única mulher a não encontrar a ruína é justamente aquela que se mostra "ativa" ou "masculina". Estes traços masculinos podem ser interpretados como indícios de sua independência em relação ao homem. Ângela furta-se ao papel de mulher doce e submissa, de mulher-anjo, e, com isso, não pode ser transformada em mulher-pervertida. Ela assume as rédeas de seu destino e acaba inclusive elevando-se acima do próprio Bertram, que vai afundando cada vez mais no lodo do crime.

Além de Ângela, também Giorgia é um caso à parte. Sua trajetória divide-se em duas etapas: uma no plano das narrativas internas, outra no da narrativa-moldura. Em "Johann", ela faz o papel de virgem doce e frágil, que acaba se tornando a vítima dos desmandos do personagem-narrador. Já no capítulo final ("Último beijo de amor"), ela ressurge como prostituta, mas conquista sua emancipação assassinando Johann. Ela é a única mulher, aliás a única vítima, que consegue vingar a violência sofrida de algum dos protagonistas. Sua fragilidade, porém, faz com que, em seguida, pereça também.

Dessa forma, a mulher que se entrega ao amor fora do casamento é castigada por Álvares de Azevedo com a morte. A despeito de todas as orgias e depravações (ou talvez exatamente por causa delas), Noite na taverna não deixa de revelar um moralismo subjacente. Esse fundo moral transparece também na linguagem do texto, que continuamente repete expressões como "mulher perdida", "mulher vendida", "amante venal", "infâmia", "profanação", "devassidão", "macilento", que deixam entrever a postura convencional e austera, que vê a liberdade sexual como algo impuro e merecedor de reprovação. Aliás, isso já foi percebido por Wilson Martins, para quem "Álvares de Azevedo tinha o sentimento profundo da culpa original e do pecado” (MARTINS, 1978, p.492). Isso significa que ele compartilha da mesma moral do seu leitor burguês. Em conseqüência, seu texto não busca defender a prostituição, o adultério, traições, excessos alcoólicos, etc., apenas escandalizar o leitor. Para Haddad (1960, p.75), Álvares de Azevedo somente está dando vazão a seu "instinto de fustigar a sensibilidade do leitor", pois seu propósito não é o de tentar subverter os moldes da moral constituída.

E, observando-se com mais atenção, notamos que certas falas de personagens parecem dirigidas ao leitor ou parecem formuladas tendo em vista um leitor implícito. Quando Bertram pergunta: "Porque empallideces, Solfieri?" (AZEVEDO, 1942, v.2, p.112), é o leitor que se presume estar empalidecendo nesse momento. Ou, pelo menos, isso seria mais coerente, do ponto de vista da organicidade interna da obra, ao invés de se imaginar isso de qualquer dos rapazes na taverna - eles próprios devassos e 
perpetradores de crimes os mais atrozes. Por outro lado, retomando o que já dissemos anteriormente, a fala citada não deixa também de ser mais um indício de que eles não são tão devassos como querem fazer crer, não passando suas histórias de simples bravatas e frutos da imaginação e do álcool.

Essas dicotomias e nuances, porém, formam justamente aquilo que torna o texto tão fascinante e desafiador. Noite na taverna representa um laboratório poético em que se faz experimentos com as categorias narrativas, inclusive com literatura dentro da literatura. Numa época em que a prosa era publicada em folhetins e pautava-se nas histórias de amor terminando em casamento (lembremos que A Moreninha é de 1844), Álvares de Azevedo explorou temas e formas de maneira absolutamente audaciosa e inovadora, sobrepujando a clássica delimitação de gêneros e ousando frustrar as expectativas do público.

Ele conseguiu - ao mesmo tempo - ampliar a literatura brasileira em duas direções opostas. De um lado, negou a visão unidimensional e idealizada do homem, explorando sua face oculta e transgressora e trazendo com isso uma dimensão mais ampla e concreta para a literatura. De outro, ele instaurou um plano abstrato e etéreo em que nada é material e no qual a literatura chega às alturas da elucubração filosófica e estética.

Álvares de Azevedo criou uma obra que, no fundo, recusa-se a contar uma história. Enredo, personagens, narrador evoluem em torno de um centro que é a própria poesia. Pensamos que é a orgia da carne, mas na verdade é a orgia do verbo. Pura ambigüidade.

\section{BIBLIOGRAFIA}

ALLEN, Walter. The English Novel. London, Penguin, 1958.

ALMEIDA, Arlenice. Uma noite contra o espírito burocrático. In: AZEVEDO, Álvares. Noite na taverna. São Paulo, Selinunte, 1991. (Coleção Oficina literária). p. 53-63.

ALMEIDA, Pires de. A escola byroniana no Brasil. São Paulo, Conselho Estadual de Cultura; Comissão de Literatura, 1962. (Coleção Textos e Documentos, 5).

AMARAL, Azevedo. Alvares de Azevedo, o unico romantico brasileiro. Revista Nova. São Paulo, v. 1, n. 3, p. 346-354, set. 1931.

AZEVEDO, Álvares. Obras completas. Ed. organizada e anotada por Homero Pires. 8. ed. São Paulo, Companhia Editora Nacional, 1942. 2 v. (Livros do Brasil, 4). 
BOSI, Alfredo. O romantismo. In:___. História concisa da literatura brasileira. 3. ed. São Paulo, Cultrix, s.d. p. 97-178.

BROCA, Brito. Românticos, pré-românticos, ultra-românticos; Vida literária e romantismo brasileiro. Prefácio de Alexandre Eulálio. São Paulo, Ed. Pólis; Brasília, INL, 1979. (Coleção estética: Série obras reunidas de Brito Broca, 1).

CANDIDO, Antonio. Formação da literatura brasileira. 6. ed. Belo Horizonte, Itatiaia, 1981. v. 2.

. A educação pela noite. In: _. . A educação pela noite e outros ensaios. São Paulo, Ática, 1987. (Série Temas, 1). p. 10-22.

GOMES, Eugênio. Álvares de Azevedo. In: ___. Prata de casa; Ensaios de literatura brasileira. Rio de Janeiro, Ed. A noite, 1953. p. 13-21.

Álvares de Azevedo e o ópio da leitura. In: __. Visões e revisões. Rio de Janeiro, Ministério da Educação e Cultura; INL, 1958. p. 62-68.

GRIECO, Agrippino. Romantismo. In: ___. Evolução da poesia brasileira. Rio de Janeiro, Ed. Ariel, 1932. p. 23-66.

HADDAD, Jamil A. Álvares de Azevedo, a maçonaria e a dança. São Paulo, Conselho Estadual de Cultura; Comissão de Literatura, 1960. (Coleção Ensaio, 9).

JORDÃO, Vera Pacheco. Maneco, o byroniano. In: _. Maneco, o byroniano. Rio de Janeiro, MEC / Serviço de Documentação, 1955. (Cadernos de Cultura, 84). p. 3-21.

LEOPOLDSEDER, Hannes. Der Weg zum literarischen Nachtstück der Romantik. In: _. Groteske Welt; Ein Beitrag zur Entwicklungsgeschichte des Nachtstücks in der Romantik. Bonn, Bouvier Verlag, 1973. p. 18127.

MARTINS, Wilson. História da inteligência brasileira. 2. ed. São Paulo, Cultrix, 1978. v. 2.

MOISÉS, Massaud. História da literatura brasileira. São Paulo, Cultrix, 1984. v. 2.

NEHRING, Wolfgang. Gothic Novel und Schauerroman. Tradition und Innovation in Hoffmanns 'Die Elixiere des Teufels'. E. T. A. HoffmannJahrbuch. Berlim, v. 1, p. 36-47, 1992/1993.

PRADO, Décio de Almeida. Um drama fantástico: Álvares de Azevedo. In: .PRADO, Décio de Almeida. O drama romântico brasileiro. São Paulo, Perspectiva, 1996. (Debates, 273). p. 119-142.

ROCHA, Hildon. Álvares de Azevedo visto por alguns críticos e historiadores literários. In: AZEVEDO, Álvares de. Noite na taverna. 5. ed. Rio de Janeiro, Francisco Alves, 1991. p. 9-18.

SERRONI, Cristine. O desejo de narrar. In: AZEVEDO, Álvares. Noite na taverna. São Paulo, Selinunte, 1991. (Coleção Oficina literária). p. 45-50. 
TODOROV, Tzvetan. Introdução à literatura fantástica. Trad. Maria Clara Correa Castello. São Paulo, Perspectiva, 1975. (Debates, 98).

VOLOBUEF, Karin. Frestas e arestas: A prosa de ficção do Romantismo na Alemanha e no Brasil. São Paulo, Edunesp, 1999. (Coleção Prismas). WIESE, Benno von. Novelle. Stuttgart, Metzler, 1963. 